\title{
Research on Comparisons between Civil Initial Service Procedure of Germany and Japan
}

\author{
Xiaoli Wu \\ College of Jincheng \\ Nanjing University of Aeronautics and Astronautics \\ Nanjing, Jiangsu, China 211156
}

\author{
Rong Wang \\ College of Jincheng \\ Nanjing University of Aeronautics and Astronautics \\ Nanjing, Jiangsu, China 211156
}

\begin{abstract}
In Germany and Japan, civil initial service procedure is deployed in indictment accepting phase. Legal and effective initial service is an important standard to judge pending action opening and is an indispensable part to make civil action between two countries render into a judicable case of court from the accuser's prosecution. In specific design of procedure, requirement of "definition" of domicile of party concerned for accuser pleadings in two countries' laws reaches the standard of requirement of prosecution of "be able to accurately deliver to defendant" instead of staying in the standard of "sufficient to differentiate defendant from other people" adopted by parties involved in traditional procedure of delimitation. As to unfavorable results due to accuser failing to provide accurate address for service and leading to failure of initial service, two countries' laws both stipulate it borne by accuser. As an exception of refusing failed initial service, both two countries' laws have strict procedures for limitation of service by publication, both showing special attention to summoned person's procedural interest. Through exploration on three aspects of positioning of civil initial service procedure, stage of procedure unfolding and procedural result of failed service, we can see that two countries' civil initial service procedures show the feature of party-leading legal proceedings in civil law countries.
\end{abstract}

Keywords — civil initial service; pending action; unsuccessful delivery; procedure structure; party-leading lawsuit system

\section{INTRODUCTION}

"Difficult service" in civil action is mainly reflected in initial service to defendant after court places a case on file. As implementation basis of initial service, legal text and juridical practice are main tools for observation and analyzing and are entity and carrier of analyzing relevant civil action system and lawsuit system. As a type of lawsuit system, continental law system's civil action system is widely applied all over the world and is adopted by many continental European countries and Asian countries. China's civil action inherits continental law's features in many aspects, especially in specific litigation text and lawsuit system. China is mainly influenced by Germany and Japan and is very different from French civil procedural law. In the following, I only take Germany and Japan directly inheriting and accepting German law as representative of civil law system and study these two countries' civil initial service procedure's legal text and legal practice, which may providing a useful reference background

Fund Project: Philosophy and Social Science Research Fund project in Jiangsu Province Universities, The research on the front deploying Civil initial service of process: Centered on procedural justice. Fund Project number: 2015SJD041. for explaining difficult service phenomenon faced by China at present.

\section{INTERPRETATION OF GERMAN CIVIL INITIAL SER VICE PROCEDURE}

\section{A. Legal and Effective Initial Service Is the Standard to Judge Whether a Pending Action Is Open and Is an Essential Element of German Civil Action}

In terms of legislation, Paragraph 1, Article 253 and Paragraph 1, Article 271 in German Civil Procedure Act stipulate that prosecution develops with proceeding of indictment delivery and indictment should be delivered instantly. Seeing literally, German civil procedure act's initial service is not an independent action at law. Instead, it is just an auxiliary way of prosecution. However, it does not influence its important procedural status in indictment acceptance phase as an important requirement of prosecution. It is because that according to German civil procedure act, for an important indication whether a prosecution is completed, pending action's criterion is condescendence delivered to defendant. Pending action is a real legal term in German civil procedure act and it is a kind of abstract summary of the whole litigation procedure from prosecution to the end of litigation in law. Seeing from beginning point, formation of pending action means that the party's "prosecution" passes examination of law and judicial authority and transfers into a case for trial in court, and judicial proceedings officially launch. With formation of pending action, prohibition of second prosecution and continuing jurisdiction in procedure, prescription halt, scheduled period interruption in entity and other legal effects generate at the same time. Relevance between pending action and initial service mainly involves with when and on which condition pending action is established. According to stipulation in Paragraph 1 and Paragraph 2 of Article 261 in German Civil Procedure Act, pending action begins with prosecution and takes place when condescendence conforming to formal requirements is delivered. Therefore, in German law, pending action is the main mark of official opening of judicial proceeding and effective initial service is the main standard to judge whether pending action opens successfully. It is worth noting that as an important procedural result of pending action, basic rules of prescribed period for litigation discontinuance and other substantial law effectiveness in German law also give prominence to importance of initial service procedure. 
According to stipulation in German Civil Code, discontinuance effect of prescribed period for litigation occurs in pending action, namely delivery of indictment to defendant by court. But with completion of delivery and submitting indictment, discontinuance effect can also date back to the time when accuser submits indictment to court. It is thus clear that in Germany, action is not brought with delivery of indictment to court. Action is completely and successfully brought with delivery of indictment to defendant. Only through legal and effective initial delivery, can accuser's right of action be really implemented in judicial practice instead of declared rightjudicial guarantee claim in civil code on paper.

The above requirements in German legislation get further confirmation in operation specification. In juridical practice, complete indictment acceptance procedure of Germany consists of three steps: The first is party involved submits indictment to court. German civil court's case filing investigation adopts file register. Upon arrival of party's indictment at court, the case belongs to court. It not only signifies opening of accuser's right protection, but also signifies legal relation of procedure firstly generating between accuser and court. The second is that the court records legal investigation on indictment before delivery. After placing on file and taking party's litigation cost, court clerk presents indictment to chief judge and chief judge will conduct formal examination on accuser's action introducing legal proceedings and thus decide whether to conduct initial service to defendant. After case filing investigation and affirming satisfactory conditions, the court will deliver indictment duplicate to defendant according to authority. The third is that indictment has to be delivered to defendant in a legal and effective way. Only after indictment is delivered to defendant effectively, can judge give judgment or judgment by default be adopted. Without delivery, there will be no prosecution.

\section{B. It Is Accuser's Obligation to Provide Defendant's Accurate Address, Therefore Inaccurate and Unsuccessful Delivery Will Directly Lead to Court'S Rejection}

Item 1, Paragraph 2, Article 253 in German Civil Procedure Act stipulates: "Accuser has to clearly state both parties in indictment". This basic rule involves with a series of explanation at the same time. According to stipulation in Paragraph 4, Article 253 and Article 130 in German Civil Procedure Act, indictment should clearly show name, identity or job, living address of both parties and their statutory agent and both parties' status in litigation. As to party's living address which is the most difficult to clarify, German civil procedure act's requirement for defendant's address is "an address where indictment can be directly delivered and which can be summoned." Namely, "definition" of defendant's address recorded in indictment by accuser has to reach the standard of direct implementation of accurate and effective initial service, which is clearly different from the standard of "sufficient to differentiate defendant from other people" adopted to demarcate procedure parties traditionally. In juridical practice, judge would inform accuser of looking for defendant actively and failed delivery directly leading to court's rejection. It is thus clear that in German law, civil initial service is completed by court through public right superficially, but the key of completion depends on accuser. Accuser is obliged to provide accurate living address of defendant in indictment, whose primary function is helping court complete delivery effectively and ensuring judicial proceedings pushing ahead.

\section{Service by Publication System under Unsuccessful Initial Service Situation Reflects Special Attention to Summoned Person's Procedural Interest}

As an exception of rejecting failed service, Germany also stipulates initial service applied to service by publication. Considering protecting summoned person's procedural interest, German civil procedure act stipulates strict application standard and judgment procedure of service by publication. According to stipulation of Paragraph 1, Article 185 in German Civil Procedure Act, only when "summoned person's address is unclear and it is impossible to deliver to agent and authorized summoned person", can service by publication be adopted. At the same time, German civil procedure act has a clear procedural explanation for "unknown residence". Under powerful protection of German administration of residents and residence registration system, the court will conduct strict survey and check on the fact that accuser fails to provide accurate service address of defendant. Only when accuser really cannot provide accurate address of defendant, can service by publication be adopted. It indicates that Germany obeys the general thought of regarding rejecting failed service as principle and service by publication as exception in design of initial service, reflecting special attention to summoned person's procedural interest.

It is worth noting that Germany issues Reform on Law of Service Procedure in Juridical Proceedings in 2002 and reforms civil service. Although establishing and strengthening stipulation of supplement service is important content of this reform, it increases litigation risk of "unsuccessful delivery" to summoned person to some extent. However, this reform does not involve with procedural positioning of initial service and result of unsuccessful delivery. Effective initial service is still a requirement of prosecution stipulated by German civil procedure act. Besides, as a whole, reformed delivery system puts forward higher requirements for parties' cautiousness and integrity. Idle litigant participant has to bear more litigation risk and is easier to suffer unfavorable result of failed delivery due to his/her own reason. The author thinks current German law's distribution of initial service litigation risk between accuser and defendant is roughly balanced.

\section{INTERPRETATION OF JAPANESE CIVIL INITIAL SER VICE PROCEDURE}

\section{A. Initial Service Is a Necessary Condition of Bringing a Lawsuit in Japan's Civil Action and It Combines with Party's Action Introducing Legal Proceedings to Unlock the Link of "Prosecution" in the Pleading Process}

Seeing from legislation, Japan's civil action has a more direct and clearer positioning of initial service compared with German law. The requirements of prosecution stipulated in Japan's civil procedure act include party's delivery of indictment to court, necessary events recorded in indictment, 
accretion of material stipulated by law, pasting corresponding stamping of litigation amount and delivery of indictment to defendant. In practice, Japan's indictment acceptance procedure rule has no big difference compared with German law. Filing of prosecution is also accuser delivering indictment to tribunal, chief judge conducts formality examination on indictment and delivers it to defendant, three steps in total. According to Japan's authoritative academic, proceeding phase structure theory put forward by Hideo Nakamura, a famous scholar, makes initial service's judicial phase positioning more specific and clearer. In Hideo Nakamura's theory, requirement of prosecution is an essential condition of litigation law filing. Without this condition, even though action introducing legal proceedings exists, it is regarded as non-setting up in procedural law. Conditions of bringing a lawsuit include necessary recording stipulated by law and delivery of indictment to defendant.

After Japan passes civil procedure modified act in 1996, judicial circle takes promoting prosecution efficiency and practical prosecution procedure as basic goal and strengthens chief judge's control of preparation procedure before trial. The part concerning initial service procedure is embodied in newly added pre-pleading note system. In practice, after indictment passes formality examination, the umpire or collegiate bench's chief judge in charge of trial will grant accuser "letter of inquiry", which usually does not involve substantive content of the case. It aims to listen to procedural development situation from accuser and accuser's opinion of it. Content involving initial service mainly includes whether it is difficult to deliver indictment to defendant, whether defendant may be absent when opening a court session, whether service by publication is needed and so on. Under necessary circumstances, umpire can authorize the clerk to inquire proceeding of relevant procedure through phone. Hereafter, at the same time of assigning session opening date of the first oral argument by umpire, the clerk conducts initial service. The author thinks in terms of purpose and content, party inquiry system in Japan's new civil procedure act has become a part of Japan's initial service system. What's more, with adding of inquiry system, initial service procedure is embedded in Japan's indictment acceptance phase more deeply and the whole indictment acceptance phase roughly presents proceeding structure of "submitting indictment-hearing a complaint-party inquiry (advance preparation of implementing initial service)designation of date for the first oral argument - initial service" in litigation route.

There is opposite theory concerning formation time (namely, the so-called accusatory time) of pending action in Japanese educational circle. Japanese scholars have different summaries of this dispute. For example, Hideo Nakamura thinks understanding of litigation effectiveness generating upon initial delivery of indictment to defendant occupies the leading role while Shindo Koji thinks that the majority proposition of accuser presenting indictment is the generation time of pending action. Combining with stipulation in Article 13, 138 and 147 in Japanese Civil Procedure Act and Item 2 of Article 152 and Article 149 in Japanese Civil Law, we get to know that discontinuance of Japanese civil action limitation begins with accuser submitting indictment or starting oral complaint and it may be rejected and eliminated due to unsuccessful delivery of accuser's indictment to defendant. As an important result of substantial law in pending action, compared with the action at law of accuser's prosecution, Japanese law's initial service seems to have more powerful influence on whether prescribed period for litigation discontinues. It seems to prove correctness of the view that pending action generates in initial delivery of indictment to defendant from another side.

\section{B. It Is Accuser's Obligation to Provide Accurate Delivery Address of Defendant and Accuser Should Suffer Unfavorable Result Due to False Address and Unsuccessful Delivery}

According to stipulation in Paragraph 2 of Article 138 and Paragraph 2 of Article 137 in Japanese civil procedure act, as to the situation of unsuccessful initial service, chief judge's handling method is the same as that of unsatisfied other prosecution conditions. Namely, chief judge has right to urge accuser to correct his/her defects in a proper period of time. If accuser refuses to compliment and correct, chief judge should reject indictment in an imperative form, namely deciding to refuse it.

Although Japanese civil procedure act does not directly stipulate that accuser has the obligation to provide accurate address of defendant, in juridical practice, court does not undertake the responsibility of looking for and investigating defendant's address. If initial delivery fails due to unclear address of defendant recorded in accuser's indictment, service personnel usually will sign a "unknown resettlement destination" tag and send indictment back to court. Court clerk will contact accuser and orders him/her to further investigate defendant's address, make corrections and report to court. If accuser refuses or is idle about looking for defendant and does not conduct corrections and conditions are unsatisfactory to apply service by publication, chief judge should reject indictment in accordance with the command.

\section{Service by Publication in the Situation of Unsuccessful Initial Service Takes Party'S Application as Principle and Has Strict Procedural Restriction}

Similar to Germany, Japan also stipulates exceptions of rejecting unsuccessful initial service, namely initial service applies service by publication. According to stipulation in Item 1,2 and 3 of Article 110 in Japanese civil procedure act, Japanese service by publication has two types: party application and court decision in accordance with power. Out of special attention to potential defendant's interest, on the one hand, Japanese civil procedure act strictly limits party's application conditions of service by publication to impossibility to get defendant's address and impossibility to use service by mail. Beside, applicant has the responsibility to prove the fact that he/she does not know residence of defendant. On the other hand, strictly forbid that court's service by publication in accordance with power is applied to initial delivery to defendant. Namely, in principle, initial delivery to defendant can only adopt service by publication according to party application instead of court's power. Only in a very few situations that defendant is suddenly missing 
after indictment is initially delivered to defendant and accuser does not put forward application of service by publication, can the court decide to adopt service by publication in accordance with power in order to avoid prosecution delay. Seeing from overall effect, there are very few cases suitable for adoption of service by publication in juridical practice. Some local courts' number of cases suitable for adoption of service by publication only occupies $0.2 \%$ of the total number of cases, at most $2 \%$. It is thus clear that Japan's limitation of above conditions of adopting service by publication for initial service effectively wipes out chances for accuser to take advantage of judicial process in an evil way and reduces the cases that judge launches discretionary power in service by publication procedure in practice.

\section{CONCLUSION}

As a process, litigation relations constituted by prosecution's sequence, phase, function, procedural result and various procedural subjects are important factors to determine whether justice can finally be realized. It is certain that comparison between structures including these factors is an important topic of civil procedure act. As to stipulating elements of prosecution structure, investigation can be done from different angles. The above text mainly focuses on combing and analysis of civil procedure act of these two continental law countries of Germany and Japan around the three aspects of positioning of civil initial service procedure, procedure expansion phase and procedural result of unsuccessful delivery. Through research, we can find that although these two countries has slight difference in some procedure designs' details, their civil initial service system shows a kind of typical lawsuit system feature. What is the most prominent is that these two countries' civil initial service is closely related to pleading and registering system. Initial service is arranged in indictment acceptance phase and is a condition of prosecution. From this kind of connection, we can clearly see that both parties' equal status in prosecution, independent right of action, self-shouldering of litigation risk and responsibility and other typical features of party-leading mediation model lawsuit system. In addition, the author thinks that this kind of system design makes initial service have an additional important and new procedural protection function apart from traditional informing and notification that is procedural structure function with rivalry debate as basic structure. Seeing from phases of procedural expansion, this kind of phase structure function of initial service not only makes civil procedure show adversary procedural feature at the beginning of procedure unfolding(indictment acceptance phase), this kind of adversary procedural feature extends to preparation procedure before trial and even final phase of holding a hearing. This kind of procedural structure ensures that both parties can conduct tactical intervention through evidence and proposition in a highly institutionalized debating process in subsequent procedures and provide information of dispute fact for the judge to an extreme, thus urging the judge to make adjudication conforming to procedural justice. Features shown in the above procedural structure maybe exactly reflect the difference between civil action court authority intervention lawsuit system and party-leading lawsuit system.

\section{REFERENCES}

[1] Ar. Blomeyer: Types of Relief Available, Martinus Nijhoff, 1980.

[2] Sir Jack I. H. Jacob: Reform of Civil Procedure, Sweet and Marxwell, 1985.

[3] Friedenthal, Kane and Miller: Civil Procedure, 2nd edition, West Publishing Company, 1985.

[4] E. G. Cohn, etc: Manual of German Law, Oceana Publications, 1971.

[5] J. Mark Ramseyer, "Reluctant Litigant Revisited: Rationality and Disputes in Japan”, 14Journal Of Japanese Studies, 111 (1988).

[6] Takeyoshi Kawashima, "Dispute Resolution in Contemporary Japan", in Von Mehren ed., Law in Japan, 39, Harvard, 1963. 